\title{
Review
}

\section{Living alterities: Phenomenology, embodiment, and race}

\author{
Emily S. Lee \\ State University of New York Press, Albany, NY, 2014, 292 pp., \\ ISBN: 978-1438450155
}

Contemporary Political Theory (2016) 15, e11-e14. doi:10.1057/cpt.2015.11;

published online 24 February 2015

Critical race theory often finds itself in the paradoxical position of denying the ontological weight of race: if (as is well-established) race is not a biological fact then, it is often asserted, it is does not 'really' exist; it is but a contingent cultural construction which may - and should - be eliminated in a new post-racial order. In contesting such 'racial eliminativism,' many of the authors in this edited volume seek to reaffirm the role of human bodies as sites of racialized perception and experience in ontologically significant and yet non-biologistic ways. To do so, most of them draw insight and inspiration from the rich resources of the French phenomenological tradition. This is a tradition that focuses on the meaningfulness of 'lived' sentient and affective experience, insisting that the significance of such embodied experience should not be displaced by privileging the traditional Western thinking subject (or, one might now add, by privileging the functions of discursivity, as some post-structuralists are wont to do).

In her Introduction, Emily S. Lee stresses the importance of Maurice Merleau-Ponty's phenomenology as a resource for exploring the ways in which race today acquires embodied, ontological weight. In addition, Frantz Fanon, Simone de Beauvoir, Jean-Paul Sartre and Henri Bergson, as well as recent phenomenologically-inspired feminist theorists, are sources of insight for various of the authors. However, what is presented under the rubric of 'phenomenology' in this volume is methodologically quite diverse. For some authors phenomenological method is a formal technique for the systematic disclosure of pre-cognitive phenomena. Notable here is Alia al-Saji's wonderful account of the moment of temporal 'hesitation' that accompanies perception, a moment, which, she argues, may enable one to disrupt habitually racist ways of seeing others. For others, however, phenomenology serves as a loose label for exploring the generalized meanings of social phenomena, as in David Carr's rich meditations on the fluid meanings of 'edges,' 'frontiers' and 'borders' with reference to the US-Mexican 'Frontera.' Some authors proceed from their own experience and write in the first person, as George Yancy 
does in his account of how he, a black man, comes to experience himself as 'fixed' in the ubiquitous white racist gaze. Others, in contrast, write in an impersonal vein; they do not locate themselves in their work or indicate a racial identity of their own.

The 11 essays assembled here are not only methodologically but also topically heterogeneous. Topics range, among others, from personal narratives of lived experience to Charles Mills's reflections on how an enlarged conception of Marxist materialism could help to elucidate how race operates, Donna-Dale Marcado's discussion of how presumptions about a person's intellectual capacity are shaped by perceived racial and gender differences, Namita Goswami's meta-reconsideration of Gayatri Spikak's anlysis of sati, and David Haekwon Kim's reflections on the shame and self-contempt that may accompany efforts by Asian-Americans to assimilate to whiteness. However, while each essay in the volume is in itself both interesting and high quality, the fact that each focuses on 'race' in some manner and that most in some sense engage with 'phenomenology' does not provide the volume with a great deal of coherence. It is thus unfortunate that Lee did not do more work in her Introduction to draw out some of the ways that various articles 'converse' with each other and invite to further discussion. Conversations that weave through the volume include, among others, whether or how unconscious, habitual racism may be disrupted; diverse ways to theorize the interplay between lived experience and large-scale structural constraints; and how far white responsibility for racism is an individual matter.

However, the predominant 'conversation' in the volume concerns the extent to which racial identities may (or may not) be immobile substances. For Yancy, in White Gazes: What it Feels Like to be an Essence, black and white positions are so overdetermined that subjection to the white gaze leaves him no escape from his essentialist designation as an animalistic black man, a potential rapist. He describes entering an elevator in which an already-present lone white woman clutches at her bag as he arrives. He insists that even if this particular woman's action might not have been racist he is justified in presuming it was. 'And what if I'm mistaken about her?' he asks, replying: 'being epistemologically mistaken does not make a difference in terms of the lived experience of what it means to undergo the experience of being stereotyped.' Rather, "knowing", within the context of the elevator, has to do with the larger community of intelligibility within which people of color come to understand white ways of being, white ways of stereotyping, and modes of white racist comportment' (pp. 60-61). Here, the woman can no more avoid being stereotyped by him as a white racist than Yancy can avoid being the stereotypical hyper-sexual black male. Both he and the white woman are locked (albeit from radically different positions of power and privilege) in a wider, socially constituted, vicious circle of essentialized identity.

An analogously essentialized identity is attributed to white people in Lee's own article, 'Body Movement and Responsibility for a Situation,' where she argues that white privilege is ubiquitously expressed in certain styles of movement and ways of occupying space, in embodied habits which it is the duty of 'responsible race traitors' 
(p. 245) to reveal and resist. However, other authors in the volume seek to stress, indeed to celebrate, the fluidity or ambiguity of identities. For example, Gail Weiss argues that one should not try to pin down Jewishness, for there is 'an essential indeterminacy as a constitutive and positive feature of Jewish identity'(p. 214); while identifying herself as a ' Nicaraguan-born, bilingual, lesbian, academic Latina, living in the United States' (p. 177), Mariana Ortega celebrates 'multiplicitous selves,' and argues against the search for safe 'homes' by people of color. She instead urges employing 'hometactics' whose aim is 'the production of a sense of familiarity in the midst of an environment or world in which one cannot fully belong, due to one's multiple positionalities' (p. 182).

Within the US context some racial identities, notably blackness, do appear to be more monolithic while others are more mobile and ambiguous. Quite a few of the authors in the volume also present whiteness, as well as blackness, as monolithic. Whiteness is presented as an essential identity: A unified, hegemonic oneness, it oppressively constitutes various non-white identities as its 'others.' Thus, the final article in the volume, Linda Martín Alcoff's 'The Future of Whiteness,' breaks radically new and important ground in insisting on the growing ambiguities and potential value of whiteness itself. 'Being white these days,' Alcoff quotes Nell Painter as saying, 'is not what it used to be' (p. 256). Alcoff certainly does not want to deny the persistence of white privilege and white racism, and of what she calls 'white vanguardist ideologies.' However, demographics are shifting so that within a few decades whites will cease to be the racial majority in the United States, while spatial and material boundaries are becoming more permeable, and, for many whites, their whiteness assures them fewer privileges than in the past. In such a situation, white identity is becoming increasingly insecure and complicated. For many whites, she argues, a variant of what W.E.B. Du Bois called 'double consciousness' is emerging. Although, unlike blacks, whites are not oppressed by a racist gaze, they increasingly experience 'a split consciousness between the way they see themselves and the way they are seen by non-white others' (pp. 272-273). Some responses to this 'incoherence' may be regressive (increasing hate crimes; Tea Party politics). But the discomfort of split consciousness may offer others an opening toward progressive political activism.

Alcoff agrees with other authors in the volume that racial eliminativism is not an option, but she poses the rarely-asked question whether, this being the case, there may not be grounds for reassessing the meaning of whiteness positively. 'What,' she asks, 'would it mean for whites to become more positively embodied as white within a multipolar social landscape?'(p. 278). While urging that whiteness needs to be displaced from its 'vanguardist' claims to be the universal site of 'civilization,' instead accepting its place as 'a particular among other particulars,' she also insists that 'despite the ample evidence of white delusions, it is a mistake to assume, as some critical race theorists do, that the first-person lived experience of whiteness should be approached only as something that needs to be deconstructed and critiqued' (p. 262). 
Alcoff's provocative claim here poses a challenge to many of the other authors in the volume. Her essay thus provides the book with a finale that ought also to become the beginning of a significant new conversation.

Sonia Kruks

Oberlin College, Oberlin, OH, USA sonia.kruks@oberlin.edu 